\begin{tabular}{rr}
\hline $\mathcal{A}$ & Titus Cristureanu - Leading Figure of the Romanian International Business \\
and Economics Higher Education Tradition
\end{tabular}

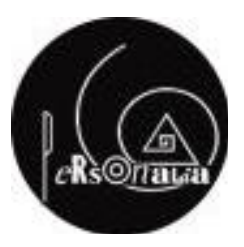

\title{
TITUS GRISTUREANU - LEADING FIGURE OF THE ROMANIAN INTERNATIONAL BUSINESS AND ECONOMICS HIGHER EDUCATION TRADITION
}

\author{
Mihai Korka
}

University of Economic Studies, Bucharest, Romania

Please cite this article as:

Mihai Korka, 2019. Titus Cristureanu - Leading Figure of the Romanian International

Business and Economics Higher Education Tradition. Amfiteatru Economic, 22(51), pp. 480-488.

\section{DOI: $10.24818 / \mathrm{EA} / 2019 / 51 / 480$}

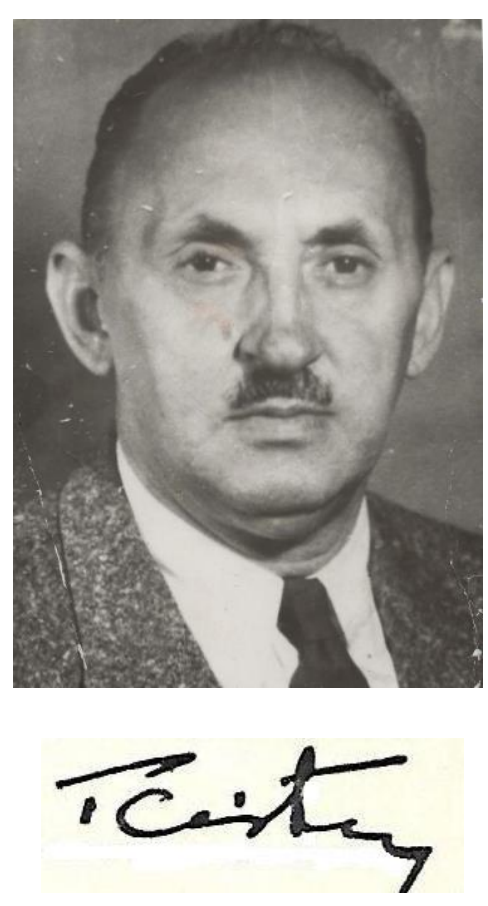

In just few years, between 1952-1958, the post-war Romanian higher education in Foreign Trade Economics had been set up and repeatedly reorganized: The Foreign Trade Institute was founded in 1952 in Bucharest, and only in three academic years disbanded, foreign trade education having been integrated into the Institute of Economic Sciences and Planning (today's Academy of Economic Studies in Bucharest / ASE, ) first as a separate school, and then as a department of the Faculty of Commerce. One of its leaders then was Professor Titus Cristureanu - having had relevant experience in diplomacy and international negotiations. Back in 1934, Caius Bardoși, holding a Phd in Law, making reference to one of his volumes, wrote: ,, The book may and should be read by any intellectual wishing to get educated and oriented in today's world chaos". At ASE, Dr. Titus Cristureanu became known as a Professor of Foreign Trade Statistics at the Department of Economic Computation and Economic Cybernetics. At the same time, starting with the mid-sixties, he was appointed as a PhD adviser at the Faculty of Commerce. (Nicolae Lupu) 
Over its one-century long existence, the Academy of Economic Studies has benefitted from the presence and academic activity of a great number of personalities. Few of them had a contribution similar to Professor Titus Cristureanu's involvement in the life of community. He excelled in such areas as socioeconomic journalism, diplomacy, international representation and negotiation, international trade in higher education, historical and cultural studies through his critical and advocating spirit, ardent patriotism, professionalism and competence sustained by research and judicious analysis of events and contexts, as well as by his dignity, modesty, realism and rationality. The above mentioned epithets are just a few of the most common appreciations given by the press of the time to his articles, brochures and books published over a 60 -year long period of time.

The premises of this sincere, deep and competent involvement in the intellectual movement for the progress of Romania had been rooted both in his comprehensive education obtained through hard work

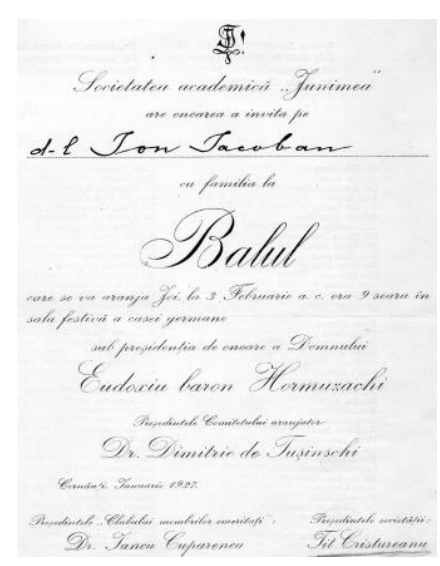

A 1927 invitation issued by the Academic Society of Romanian students „Junimea” having Tit[us] Cristureanu as president of the Society and harsh competition in a multicultural, multidisciplinary and multilingual environment of the University of Chernovtsy [Cernăuți], as well as in his sincere and passionate love for his country, language and people as the president of the Academic Society „Junimea” of Romanian students in Cernăuţi back in 1927.

The patriotic pathos and progressive militancy of the future professor had manifested in several hypostases over a long and agitated 20th century: becoming an fervent antirevisionist, when the requests for redrawing European borders made by World War I losing parties became outrageous at the end of the 1920s; being entirely against racism and fascism, when the right-wing nationalistic extremist movements in Romania and in other European countries won a worrying popularity among the masses in the 1930s.

Titus Cristureanu was a left-wing intellectual in all circumstances of his personal and professional life. He expressed repeatedly his militant opinion in numerous articles issued in the press of the time as well as in many interviews.

\section{Life}

He was born on February 5, 1904, in the family of Vasile and Paulina. Vasile Cristureanu worked for the Romanian Railways as Chief of the Ițcani train station, at the frontier with the Duchy of Bukovina, and his wife, a former teacher, was a house wife. Their only child attended the gymnasium and high-school in Câmpulung Moldovenesc. He had been for one academic year student at the Polytechnic School in Timişoara, and then got enrolled to the Law Faculty at the University in Chernovtsy [Cernăuți], which he graduated with Magna cum Laudae in 1926. After graduation, he was employed as a trainee lawyer at the wellknown Law Firm „Gheorghe Vântu” in Cernăuţi. 
During his student years in Cernăuţi, and after graduation, he had been an active member of the Academic Society „Junimea” of the Romanian students by getting involved in various artistic events, literary evenings and historical evocations, in organising conferences and reading events. The artistic and scientific education of Romanian communities in the cities and villages of Bukovina was the way in which „Junimea” aimed to cultivate patriotic feeling and preserve national and linguistic identity. Through the voice of Titus Cristureanu, at the Congress of National Student Movement in Blaj, on May 15, 1925, the „Junimen” of Cernăuți expressed once again their adherence to values of Romanian spirituality.

In 1928, Titus Cristureanu won a scholarship for doctoral studies at the London School of Economics and Political Sciences - LSE, at that time a constitutive college of University of London. He attended the courses and passed the examinations in the field of international relations.

His PhD thesis entitled „International Co-operation. A Study of its Causes and Forms” investigates the theories in the area of cultural, religious, military, political and economic cooperation. The comprehensive doctoral research, reviewing and analysing the historical acts and facts in the history of mankind that resulted in cooperation of political entities, including the states, discovered that human communities had to cooperate, whether unwillingly (by physical or moral coercion), or voluntarily (out of the need to face together a threat, or out of desire to have a better life due to cooperation) (pp. 327-328 in the doctoral thesis).

The author of the $\mathrm{PhD}$ thesis draws the attention on the fact that the forms and causes of cooperation are often interchangeable as functions generating cooperation: a form of geographic, ethic and/or psychological cooperation may appear due to an interaction, as well as the same cause may be the origin of different types of cooperation. With all the functional versatility of cooperation forms and types, the $\mathrm{PhD}$ dissertation proves by reference to real historical circumstances, and by using logical deductions, that out of all cooperation observed throughout history, only those originating in the freely expressed desire to cooperate for a better common future have the chance to endure over time. Such a cooperation results in federation or confederation of communities/states that freely agree to establish or join such a union of interests. It should be also noted that the $\mathrm{PhD}$ dissertation underlines the distinction that should be made between an alliance (a time-limited cooperation) and a confederation, made by free will of entities sharing similar ideals, traditions, tendencies, and wishing above all to have a better life/a promising future (pp. 338-339).

With this PhD thesis elaborated under the supervision of Charles A.W. Manning - a leading personality of the English school of international relations of that time, Titus Cristureanu was awarded on June 22, 1932, the Degree of $\mathrm{PhD}$. According to a tradition of the University of London, the event was recorded in the 1932 registry in the archive of the House of Senate.

Upon his return to Romania, he writes more than one hundred articles in the press under his own name and/or under a pen name (Gelu Deriu, T.T., T. Tudor, Năstase-Tudor, R.P.) in such democratic newspapers as „Ultima oră”, „Adevărul”, „Dimineața”, „Dreptatea”, „Prezentul economic”. Also, he published in „Viața romînească”, „Cuvîntul liber”, „Stînga”, „Reporter”, „Secera”, „Independența economică”, „Buletinul industriei și 
comerțului” etc. During 1933-1938, he was the newspaper secretary at „Viaţa Românească”, the editor-in-chief at „Prezentul economic”. He was also the founder and Director of the „Viaţa Bucovinei” magazine.

In 1933, he was employed by the Ministry of Industry and Commerce. In 1937, he was already the head of a foreign trade department in the same ministry. For his activity in economic diplomacy, he was awarded the Order of the Crown of Romania, knight class, on the proposal of the Minister of Foreign Affairs, as well as the Commercial and Industrial Merit Medal in 1940.

In 1939-1942, he was first trade attaché of the Kingdom of Romania in Moscow, and then in Istanbul. From 1942 until the end of World War II, he had been working at the Ministry of Foreign Affairs. After the war, he had been a member of the group of Romanian experts, who took part in negotiating the Paris Peace Treaty. Also, he had been present in diplomatic delegations discussing the post-war status of Romania.

In a climate of mistrust and suspicion, generated by the Soviet occupation of Romania in the first years after World War II, the removal of monarchy and the installation of a left-wing government, Titus Cristureanu had been under investigation and temporarily imprisoned in Aiud, which made him interrupt his professional and journalistic activity during the years 1947 to 1949 .

In 1949, he was employed at the Danube-Black Sea Canal Directorate, and then at the Ministry of Interior Commerce. In 1955, he was transferred to the newly founded Chamber of Commerce and Industry of Romania, where he held the position of vice-president until 1968.

Once Romania joined the UN as a member state (1955), he was appointed the head of mission in New York. In 1964 and 1966, he was the head of the Romanian delegation for the first two rounds of the United Nations Conference for Trade and

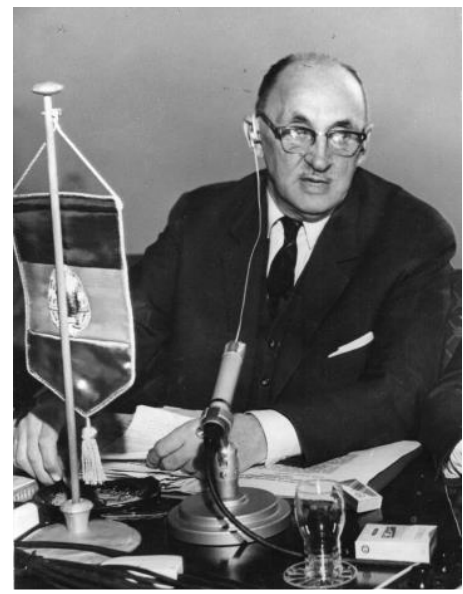

Titus Cristureanu in the beginning of the 1960's as a diplomat at the UN permanent mission Development - UNCTAD held in Geneva, and New

Delhi. He often had attended various Romanian economic missions on all continents.

As a recognition of his competence and professionalism in undertaking various missions in the country and abroad, Titus Cristureanu had been awarded orders and medals of the socialist regime, among which, the Order of Labour, I-st class (1964), the Tudor Vladimirescu Order, II-nd class (1974) and the 30 Years Anniversary of the Liberation of Romania Medal (1974).

A severe home accident in a summer night of 1989 held him permanently bedridden. He suffered in dignity, and his inquisitive mind never left him. He passed away at his residence in Bucharest on January 9, 1991. 


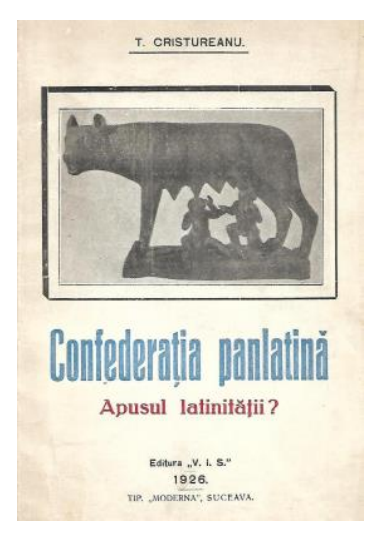

The debut book printed in 1926 by V.I.S.

Printing House in Suceava

\section{Works}

In 1926, V.I.S. Publishing House in Suceava published a paper by Titus Cristureanu, written with the pathos of a 22year-old young man. The writer's debut is marked by his indisputable maturity in the valuation of power relations on the European continent in the mid-1930s of the twentieth century. Entitled Confederația panlatină. Apusul latinității? [The Pan-Latin Confederation. The Dawn of Latinity?] the paper was a vibrant plea for the intensification of cooperation among Latin culture bearing countries as a means of defence against German-Austrian, Anglo-Saxon, Pan-Slavic, and American ,imperialism”, against the expansionist trends that had became harsh in the CarpathianDanubian-Pontic space. The call for a Pan-Latin confederation is an address towards „today's and tomorrow's generations to have enthusiasm and drive in facts and actions, a precise form of order and discipline, cooperation and solidarity ..." (p. 3). It maybe today viewed

as an utopia of the time but the young intellectual Cristureanu understood the need to act for the benefit of national interest: „It is a century when the useless speech, the so-called ballast of parliamentarism and shallow ideology have been abolished, when only an actual action is of real value. Let's get to work, then!" (Ibidem). Even a century after the publication of the book, today's reader cannot but note the variety and seriousness of argumentation, the refinement and acuteness of observations, discourse pertinence and the art of idea presentation, all contributing to a text that is easy to read, but also full of direct and indirect messages sent both to the public and the parties that were governing at that time.

Back in Romania, after having been awarded the $\mathrm{PhD}$ degree in science in London, Titus Cristureanu published a series of papers between 1934-1937 aimed to make the readers in Romania get familiar with the tumultuous agenda of international life, as well as with the ,information" on advanced capitalist economies that he had accumulated during his stay in London. So, there were published in 1934 - Caleidoscop internațional. Evenimente, probleme, aspecte [International Kaleidoscope. Events, issues, aspects] - two editions; Anglia și România. Relațiunile lor economice: 1929-1934 [England and Romania. Their economic relations: 19291934]; Uniunea Sovietică - S.S.S.R. şi România. Considerațiuni economice și comerciale [Soviet Union USSR and Romania. Economic and commercial considerations]. Other two works were published in 1935: Hotarele statice și dinamice ale României [Static and dynamic borders of Romania] and Europa agrară și Europa industrială [Agrarian and Industrial Europe].

The author published Agricultura neo-capitalistă $\hat{\imath} n$ Anglia [The Neo-capitalistic

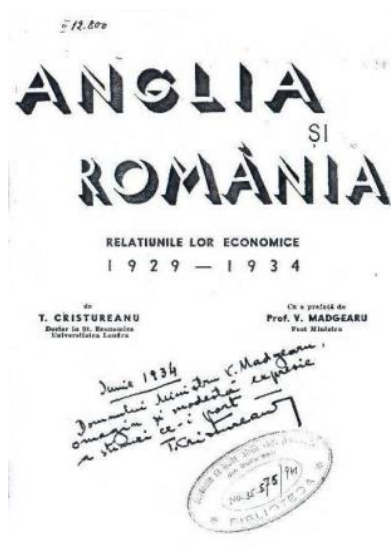

To Minister V. Madgearu, homage and a modest sign of my esteem

- T. Cristureanu 
Agriculture in England] and Imperialism [Imperialisme] in 1936, and Britannia. O analiză politică, socială, economică şi geo-politică a Imperiului Britanic [Britannia. A Political, Social, Economic and Geopolitical Analysis of the British Empire] in 1937. The press of the time abounds with eulogistic appreciations towards the author of the works, described as being serious, well-informed, sensational in terms of content, well-thought, and also written in such a way as to provide an instructional and interesting reading with practical suggestions for the governing authorities.

Two of these works should be discussed separately:

(1) Anglia și România. Relațiunile lor economice: 1929-1934 [England and Romania. Their Economic Relations: 1929-1934], a volume, in which, the great Romanian economist Virgil Madgearu wrote in his foreword: „We live now in a time of economic history when our old ways do not lead to regaining economic prosperity that we had had before the World War I... All is in deep and permanent change... Only a systematic and continuous observation of economic forces operating at high speed, completed by information for each a moment may help in providing a guide for economic policy of the country... In this context, the scientific investigation and the craft for popularisation, presented on pages that follow by Mr Cristureanu, have a great importance not only for informing the public opinion, but also for triggering the economic action of the State ..." (p. 3). Certainly, the great economist referred to the big gap between the two partner countries in the area of

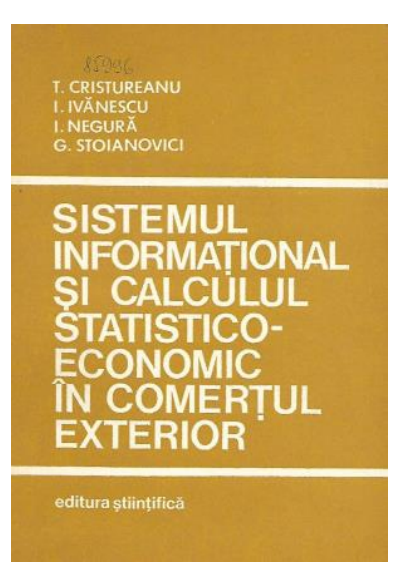

In 1974, together with other prestigious

colleagues, he signs this volume on the building stage of the information and analysis system of the Romanian foreign trade international trade in goods in terms of efficiency of transactions and their impact on national economy.

(2) Hotarele statice şi dinamice ale României [Static and Dynamic Borders of Romania], referring to which, Caius Bardoși, doctor in law of the Institute of High International Studies in Paris, stated in the ,Buletinul Institutului Economic Romînesc" (issue 10$12 / 1935$ ) that, it is a scientific review of major Romanian problems in the vast and complicated field of international relations, a work of great scientific value". Regarding the author of the book, Gogu Rădulescu observed in the „Buletinul Bibiotecii Academiei Comerciale” (issue 1/1935) that „Mr T. Cristureanu is an intelligent, competent

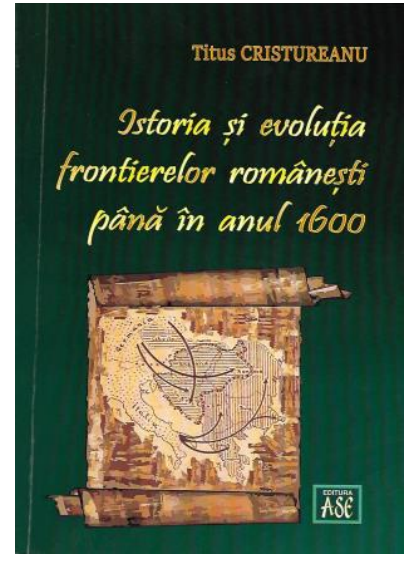

The 2018 posthumous book focuses on the necessity and utility of frontiers for the territories inhabited by Romanian communities from Geto-Dacian times until the first union of the principalities in 1600 under Mihai Viteazul

(Michael the Brave) 
and objective researcher" therefore ,the study of T. Cristureanu could be placed above all international relations studies published on our literary market".

Out of works published, based on the experience accumulated by Cristureanu as the VicePresident of the Chamber of Commerce and Industry of Romania, we should note two: România. Comerțl exterior [Romania. Foreign Trade] (1969, editions in English and French) and Sistemul informaţional şi calculul statistico-economic în comerţul exterior [The Information System and Statistical - Economic Calculus in Foreign Trade] - 1974, coauthor. Both works inform the reader on features of international trade of Romania, as well as on methods and instruments of scientific investigation of foreign trade flows.

A conclusion is undisputed: the advocating and patriotic features of Professor Titus Cristureanu's works had been continuously refined and gained even more sharpness and penetration force during his illustrious diplomatic and academic career. The book Istoria și evoluția frontierelor românești până în anul 1600 [The History and Evolution of Romanian Frontiers until 1600] was published posthumously in 2018 due to diligence of ASE Bucharest Publishing House and the efforts of Professor Cristiana Cristureanu, $\mathrm{PhD}-$ the daughter of the eminent professor. This last book is a clear proof of Titus Cristureanu's erudition and deep love for the people, country and language that he is advocating for beyond the passage to eternity.

\section{Academic career}

The foundations of higher education for future Romanian experts in foreign trade were laid in 1952 by founding the Institute of Foreign Trade. Beginning with 1955-1956 academic year, the activity of the institute was first integrated as a separate faculty, and then as a specialisation of the Institute of Economic Sciences and Planning, the precursor of today's Academy of Economic Studies in Bucharest.

Right from the beginnings of foreign trade higher education program in Romania, Titus Cristureanu accepted together with Pavel Tiberiu and Alexandru Zanfir to be part of a group of experts in international economic relations, who designed and implemented a curriculum matching the formative needs of the time. The curriculum benefited from the great experience that had been accumulated by these professionals in negotiations and in running international commercial agreements. They were soon joined by Nicolae Sută, fresh graduate of the Faculty of General Economics, who rapidly became an appreciated expert in International Trade Economics.

Titus Cristureanu stated himself what guided him in undertaking and pursuing a career of a professor and educator of foreign trade specialists back in 1934 in his book Anglia și România. Relațiunile lor economice: 1929-1934 [England and Romania. Their Economic Relations: 1929-1934]: „, Real and useful diplomacy today... belongs almost entirely to the delegates, who are in charge with waving tight economic relations between the states... with the skills, the ability and cleverness of merchants, who, above all, have a sense of reality... From here stems the importance of economic negotiations, the concern for the way in which the delegates mandated to negotiate are and should be selected, and the attention paid by most governments to foreign trade agencies..." (p. 17). 
Care in selecting the delegates empowered to negotiate, and the commercial attachés for the country's external agencies, was, in professor Titus Cristureanu's view, the motivating point for training such experts, educating them in the spirit of patriotism and professionalism, developing their responsibility, ethical and moral behaviour and their abilities to analyse the business environment on international markets and to assess the efficiency of transactions by means of theoretical and practical courses in Statistics of Foreign Trade.

For over two decades (1955-1974), initially full professor and later consultant professor, through his elegance, charm and humour, and also academic discipline and consistency, Titus Cristureanu contributed to the education of foreign trade experts in such a way that they could develop a set of high-level professional skills and be able to negotiate with foreign partners and assume decision making.

The professor published periodically teaching materials of high value to students as a single author, or in collaboration with other authors. In this sense, we should recall: Supliment la cursul de Statistica Comerțului Exterior [Supplement to the Course of Foreign Trade Statistics] (1957); Statistica comerțului exterior. Tehnica de calcul statistic și analiză economică [Foreign Trade Statistics. Statistical Calculation and Economic Analysis] (1965, edited by Professor M. Mănescu and Associate Professor T. Cristureanu); Curs de Statistica comerțului exterior. Tehnica de calcul statistic și analiză economică [Course of Foreign Trade Statistics. Statistical Calculation and Economic Analysis] (1971); Statistica comerțului exterior. Tehnica de calcul statistic și de analiză economică [Foreign Trade Statistics. Statistical Calculation and Economic Analysis] (1974, course and practical tests in collaboration with teaching assistant M. Korka) or Statistica şi calculul eficienței economice în comerțl exterior [Statistics and Calculation of Economic Effectiveness in Foreign Trade] (1977, manual for vocational post-secondary schools of foreign trade written in collaboration with N. Pop).

The 1971 book Curs de Statistica comerțului exterior. Tehnica de calcul statistic și analiză economică [Course of Foreign Trade Statistics. Statistical Calculation and Economic Analysis] is a real model of learning support in two volumes (634 pages) offered to students. It covers, for the first time in Romanian literature, the main elements of statistics of international trade in goods and statistics of international trade in services

As a sign of recognition of his scientific and academic merits, in 1965, Titus Cristureanu was nominated docent professor of the Academy of Economic Studies in Bucharest and was granted the right to supervise PhD students and doctoral thesis in the field of Foreign Trade Economics. In this capacity, Professor Cristureanu proved again to be unrivalled as he was able to combine academic and research rigour with human warmth and understanding. He was always open to new ideas and flexible in approaching the subjects under discussion tactfully and patiently with each of his $\mathrm{PhD}$ student. Only a real intellectual could embody so many qualities in one unique personality.

The fate was generous with me as I have developed as researcher and academic under professor's close supervision. I will forever remain grateful for this great experience. 
Professor Mihai Korka, PhD is an academic and researcher at Bucharest University of Economic Studies (ASE) since 1969. He is a graduate of the Faculty of Commerce (now the Faculty of Business and Tourism), Economics of Foreign Trade section. His doctoral thesis (1975) developed at ASE under the supervision of Professor Titus Cristureanu is focussing on ,,Statistical and Economic Analysis Methods of the Invisible Trade Components”.

After graduation, he accepted the proposal of Professor Cristureanu to become a teaching assistant at the Department of Economic Computation and Economic Cybernetics in a subject that is at intersection of many disciplines: Foreign Trade Statistics. A promoter of an interdisciplinary approach in research and a polyglot, emeritus professor Mihai Korka has numerous scientific contributions: over 40 books and higher education manuals (as a single author and/or co-author), 70 papers and articles published in volumes and journals in Romania and abroad, 75 participations in scientific events in the country and in other 20 countries, involvement in more than 50 relevant research grants, successful supervision of over 30 Ph.D. students in the pursuit of their research success. His wide range of competences and abilities made him suitable for holding high-level positions: General Director of ,Virgil Madgearu” National Institute for Conjuncture, Marketing and Management (1991-1992), Vice-Rector of ASE (1992-1996), General Director and State Secretary at the Ministry of National Education (1998-1999), Dean of the Faculty of International Business and Economics of ASE (2004-2008).

„His professional model is based on honesty, notable human qualities, development of defining values for higher education, respect for his own beliefs and the diversity of opinions of other people”. In 2000, he was awarded the National Order „Faithful Service” in grade of Grand Officer. 